\title{
The Construction of College English Ecological Teaching Model based on the Background of Computer Network
}

\author{
Peng Tong ${ }^{1, \text { a }}$ \\ ${ }^{1}$ Nanchang Institute of Science \& Technology, Nanchang, Jiangxi, 330108 \\ a email: tedpound85@163.com
}

Keywords: Computer; Network Background; College English; Ecological Teaching Model

\begin{abstract}
With the development of modern society and the improvement of economic level, the computer network has been inseparable from people's daily life. The traditional college English teaching model in this new environment faces both opportunities and unknown challenges. Although the computer network introduced into the classroom has enriched the teaching mode, the classroom ecological imbalance is also increasingly prominent. How to carry out efficient resource integration to promote the computer network in line with the development of modern college English teaching needs has become a widespread concern in the education sector. This paper puts forward the method of constructing the ecological teaching model of college English under the background of the Internet, and provides a reference for the research of many scholars.
\end{abstract}

\section{Introduction}

With the deepening of economic globalization and the popularity of computer network technology, people's learning and life have undergone enormous changes. The widespread use of Internet technology has also brought unprecedented impact to college English teaching. Although the teaching model of college English has changed greatly at this stage, it has completely neglected the important factors such as the integrity and relevance of classroom teaching content, and split the interrelationship between factors such as classroom, teacher, student and learning environment. The issue of classroom ecological imbalance is serious, teaching objectives increasingly utilitarian and one-sided, leading to the classroom losing its vitality. Therefore, it is of great theoretical and practical significance to explore how to construct the ecological teaching model of college English under the background of computer network.

\section{The Ecological Teaching Model}

Educational ecology is the result of the extensive application of ecological methods and principles in the field of education. It is a new discipline that connects education with the surrounding environment, and regards the association and mechanism of the two as the object of study. The main direction of the healthy development of teaching model is the ecological teaching mode. That is, in the process of teaching, the ecological classroom continues to explore the formation of ecological teaching model that can effectively promote the ecological development of classroom teaching. The theoretical guidance of the teaching model is education ecology thoroughly implementing the "people-oriented" teaching philosophy, according to the level of knowledge of students and the fact that learning needs to build a rich form of teaching activities to promote students in excellent artificial conditions of healthy and sustainable development.

The purpose of the construction of the ecological teaching model is to take into account the objective factors such as the internal and external learning pressure of the students, the actual needs of the modern society and the inherent nature of the students, and the flexible use of the subjective consciousness of the ecological subject and the positive emotional development to promote the learning and Cognition, the establishment of equality and mutual assistance, harmonious and harmonious classroom environment, so that students can learn in the free and open, collaborative exploration of the classroom environment and grow [1]. 


\section{The Shortcomings of College English Ecological Teaching Model Construction}

The whole process of learning English should be an open, interactive and interesting communication process. However, at the present stage of college English teaching process, college students as the main body of learning, have a serious lack of self-confidence, interaction and communication. Many students are willing to ask the teacher questions, while reluctant to communicate with students and to solve their own problems through their own efforts. And many college teachers who fear of college students making mistakes or wasting a lot of learning time, often over-point students or interrupt the discussion in the middle of activities, and even give the answer directly, which fails to develop students' independent thinking ability. On the other hand, there are many classrooms equipped with multimedia teaching facilities, but the teachers follow the lead of the main content of teaching courseware which causes a serious lack of innovative content and makes classes tedious. Furthermore, this can not help teachers improve teaching quality,

In the course of English teaching in the past, teachers always emphasize the use of vocabulary, grammar and sentences, and do not pay much attention to students' comprehensive language use ability. The knowledge is only mechanically taught to the students and no learning methods are introduced. Students in the process of learning, can't get into the real context. without the help of teachers, they show little promise of be creative learning. It is like pots of flowers in the greenhouse. Once suffering the loss of fertilizer and sunshine, it will quickly wither. This "flower pot effect" seriously damaging the college English classroom should introduce the ecological characteristics; or students will completely lose the ability of sustainable development and lifelong learning awareness, and they each become a test machine.

As an ecological college English classroom, we must enrich the teaching evaluation, so that it has a variety of characteristics. If you want to ensure that the classroom system as a whole healthy and sustainable development, then the diversity of teaching evaluation is indispensable. However, the evaluation of English teaching in colleges and universities has seriously violated the diversified ecological concept. The first is that the subject is too simplified. Teachers are generally teachers to learn from the results of the evaluation. Society and students' parents are unable to participate in the teaching evaluation process. The evaluation method is too monotonous, and generally used are quantitative evaluation methods. Qualitative evaluation rarely appears, not to mention those completely non-quantifiable important factors. Finally, the evaluation content is too unitary, the past teaching evaluation is to test the student's knowledge reserves and skills level, not the emotional, attitude and outlook on life and other indicators into the evaluation category [2].

\section{The Construction of College English Ecological Teaching Model in the Background of Computer Network}

The so-called ecological concept attaches importance to the coordination and sustainable development of all people in the whole ecosystem. In the context of the computer network, the ecological English teaching model must be to achieve the sustainable and healthy development of students, in-depth observation of people-oriented teaching philosophy, the goal of cultivating ecological people. Strictly follow the ecological teaching objectives, the "College English teaching requirements" among all the requirements into practice, focusing on improving the comprehensive language use of college students, especially the ability to read and write. So that they in the future of daily life and practical work, can flexibly use the acquired knowledge, and improve the level of self-learning to adapt to the needs of social development.

In the background of computer network, the teaching content of ecological English classroom should be holistic and related. First of all, the teaching content should be effectively integrated with the relevant knowledge. In the whole process of English teaching, teachers at the appropriate time can introduce linguistics, Anglo-American literature, rhetoric and translation courses related to the content, highlighting other social subjects. Especially in the interpretation of the modern paragraph, we must follow the pace of Western developed countries such as Europe and the United States. Second, the teaching content should fully reflect the relationship between the living environment 
and students, emphasizing the student's sense of contact [3].

Under the background of computer network, the ecology of college English classroom in the process of teaching should be in-depth implementation of the link, development and ecological concepts. First of all, the need to emphasize the interaction between teachers and students, teachers can not be the leader of the classroom. The implementation of a pattern, not teaching materials and teaching courseware as the only authority, should focus on students' subjectivity and subjective initiative. Give students more encouragement to help establish their self-confidence. Only in the way teachers and students are integrated into the classroom can we express a good learning atmosphere, and promote the healthy and sustainable development of teachers and students. Second, in enhancing the exchange of teachers and students, the interaction among students should be strengthened at the same time .

In the teaching strategy, the preferred should use a richer communication language to start teaching. In the classroom teaching of the past, teachers only mechanically impart knowledge and skills, but the ultimate purpose of learning the language is to be flexible to use, so teachers must use more task-based and communication-oriented teaching strategies. The colorful teaching resources are essential in the ecological college English classroom, and the diversified resources are used to expand the students' horizons while enriching the students' knowledge.

In ecological colleges and universities, English teachers and students must enjoy equal relationship between mutual promotion and mutual encouragement. Teachers should respect students, especially those with poor grades. Students should be guided by teachers, especially the correct view of the authority of teachers. Harmonious relationship between teachers and students can stimulate students' interest and enthusiasm. Classroom monitoring should strictly follow the principle of moderate. Supervision and management of the intensity can not be too strong and can not be too weak. Too strong will reduce the overall teaching effect, while too weak will waste a lot of time, resulting in students being rebellious.

First of all, the subject of evaluation must be diversified, so that college students, teachers, students' parents, universities and society can be involved in teaching evaluation, bringing about the full range of teaching evaluation. Second, the way of evaluation must also be diversified; to prevent the monotonous quantitative evaluation methods, the combination of qualitative evaluation and quantitative evaluation of the principle should be adopted. And the content of the evaluation must also be diversified. The healthy and sustainable development of the students is the ultimate goal of the ecological English teaching. The academic achievement can not be regarded as the only evaluation index, and the factors such as willpower, emotion and attitude should be included in the evaluation category. Finally, the language of the evaluation should also pay attention to courtesy, well-spoken words and courtesy language can encourage students to create an active learning atmosphere [4].

\section{Conclusion}

Under the background of computer network, the construction of college English ecological teaching model has injected new vitality into English teaching. Improving the relationship between teachers and students at the same time can promote the comprehensive and sustainable development of college students, and the smooth progress of the classroom teaching. In addition, it also effectively improves the teaching idea of teachers, so that teachers in the teaching process can acquire the overall, contact point of view to study classroom teaching, which will significantly improve the quality of college English teaching, and promote the sustainable development of educational ecosystems.

\section{References}

[1] Dou Juan. How to improve the effectiveness of college English reading and writing teaching under the background of network resources [J]. Course Education Research, 2015, 10 (2): 77-77, 78. 
[2] Wang Youhua. On the Change of the Role of College English Teachers in the Background of Digitalization [J] .Chinese Journal of Politics, Zhejiang University (Philosophy \& Social Sciences Edition), 2015,12 (8): 73-76.

[3] Yuan Chang-wan, Jin Shuangjun. Design of College English Teaching in the Context of Informationization - A Case Study of "The ABCs of the USA" [J]. Journal of Chifeng University (Natural Science Edition), 2013, 12 20): 232-234.

[4] Dong Jinping. College English intensive teaching computer network ecological environment optimization research [J]. Theoretical observation, 2016, 20 (6): 164-165. 